Int. J. Dev. Biol. 60: 229-236 (2016)

doi: $10.1387 / \mathrm{ijdb} .160113 \mathrm{sy}$

\title{
Cell-free Xenopus egg extracts for studying DNA damage response pathways
}

\author{
STEVEN CUPELLO, CHRISTINE RICHARDSON and SHAN YAN* \\ Department of Biological Sciences, University of North Carolina at Charlotte, Charlotte, NC, USA
}

\begin{abstract}
In response to a variety of DNA replication stress or DNA damaging agents, the DNA damage response (DDR) pathways are triggered for cells to coordinate DNA repair, cell cycle checkpoints, apoptosis, and senescence. Cell-free Xenopus egg extracts, derived from the eggs of African clawed frogs (Xenopus laevis), have been widely used for studies concerning DDR pathways. In this review, we focus on how different experimental systems have been established using Xenopus egg extracts to investigate the DDR pathways that are activated in response to DNA replication stress, double-strand breaks (DSBs), inter-strand crosslinks (ICLs), and oxidative stress. We summarize how molecular details of DDR pathways are dissected by the mechanistic studies with Xenopus egg extracts. We also provide an update on the regulation of translesion DNA synthesis (TLS) polymerases (Pol $\mathrm{K}$ and REV1) in the DDR pathways. A better understanding of DDR pathways using Xenopus egg extracts has opened new avenues for future cancer therapeutics. Finally, we offer our perspectives of future directions for studies of DDR pathways with Xenopus egg extracts.
\end{abstract}

KEY WORDS: Xenopus egg extracts, DNA damage response, ATR-Chk1, ATM-Chk2, TLS

\section{Introduction}

A soluble cell-free extract system from stage 6 Xenopus laevis oocytes was first used to investigate the DNA replication of simian virus 40 (SV40) in 1976 (Gandini Attardi et al., 1976). Assembly of SV40 chromatin was reported in a cell-free Xenopus egg extract system (Laskey et al., 1977). Since then, Xenopus egg extracts have been utilized for studies in DNA metabolism and cellular signaling pathways including DNA replication, DNA repair, and DNA damage response (DDR) (Blow et al., 1987; MacDougall et al., 2007; Raschle et al., 2015; Williams et al., 2012; Yan and Michael, 2009b).

The genomes of all cells are exposed to a variety of insults from endogenous and exogenous sources (Ciccia and Elledge, 2010; Yan et al., 2014), leading to DNA replication stress, doublestrand breaks (DSBs), inter-strand crosslinks (ICLs), and oxidative stress (Fig. 1). To sense and signal DNA damage and replication stress, the DDR pathways including ATR-Chk1 and ATM-Chk2mediated signaling cascades are triggered to coordinate DNA repair with cell cycle progression. Defective DDR pathways have been implicated with cancer development and neurodegenerative disorders (Jackson and Bartek, 2009). In addition, cells develop a tolerance to DNA damaging agents, possibly through the translesion DNA synthesis (TLS) pathway that include Y-family DNA polymerases (REV1, Pol $\eta$, Pol $\mathrm{k}$ and Pol ı) and a B-family DNA polymerase Pol $\zeta$ (Ho and Scharer, 2010). When DNA lesions cannot be replicated by replicative DNA polymerases (Pol $\delta / \varepsilon)$, they can be bypassed by TLS polymerases, leading to mutagenesis as a tradeoff of survival (Chang and Cimprich, 2009). Although we have acquired a better understanding of DDR pathways in the last 20 years or so (Ciccia and Elledge, 2010), the study of DDR pathways remains an intense topic of investigation, and it is a critical outstanding question of how TLS polymerases and DDR pathways regulate reach other in cellular responses to DNA damage or replication stress.

Xenopus egg extracts are an excellent cell-free model system to investigate critical questions in the field of DDR pathways (Willis et al., 2012). In this review article, we will summarize how experimental systems are established using Xenopus egg extracts to better understand the molecular mechanisms underlying DDR pathways in response to DNA damage or replication stress. We also provide an update on the positive regulation of TLS polymerases (Pol $\mathrm{k}$ and REV1) in the DDR pathways as well as our perspectives of future directions using Xenopus egg extracts as

Abbreviations used in this paper: DDR, DNA damage response; DSB, double-strand break; ICL, inter-strand crosslink; TLS, translesion DNA synthesis.

\footnotetext{
*Address correspondence to: Shan Yan. Department of Biological Sciences, University of North Carolina at Charlotte, Charlotte, NC 28223, USA. Tel: +1-704-687-8528. Fax: +1-704-687-1488. E-mail: shan.yan@uncc.edu - web: https://clas-pages.uncc.edu/shan-yan
}

Accepted: 19 April 2016.

ISSN: Online 1696-3547, Print 0214-6282 


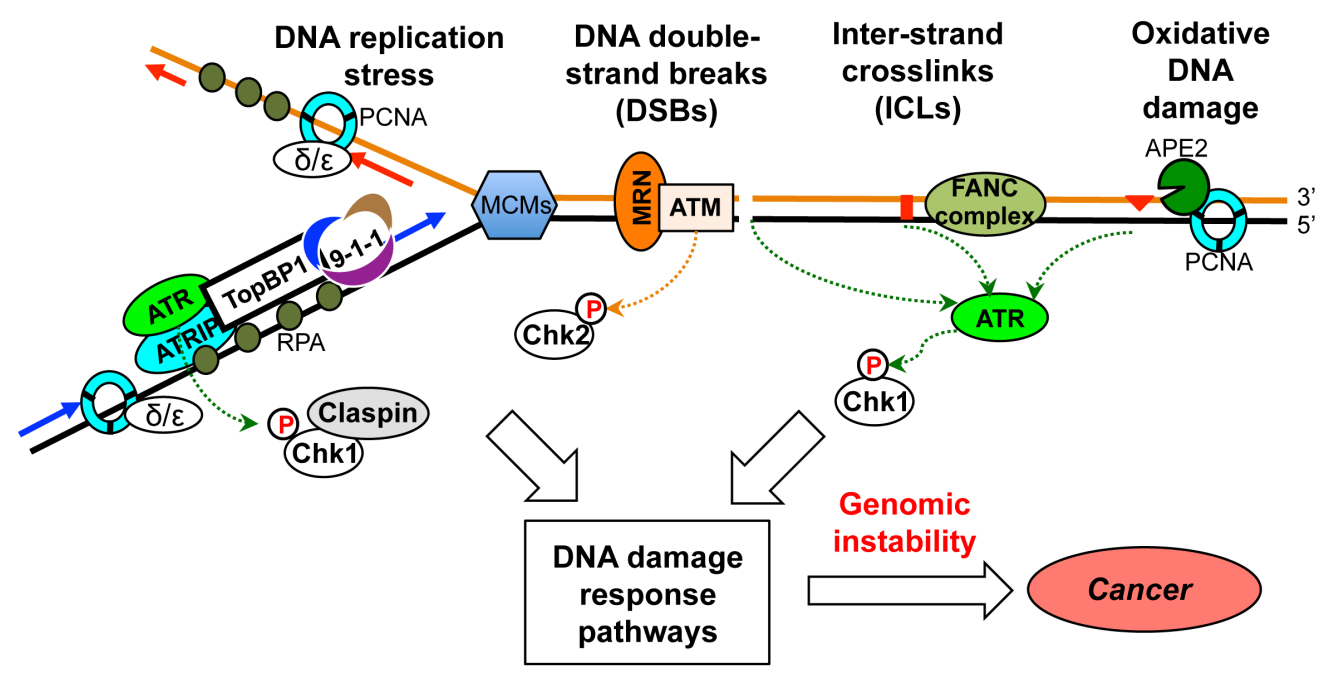

Fig. 1. Schematic diagram of DNA damage response (DDR) pathways in response to DNA replication stress, DNA double-strand breaks, inter-strand crosslinks, and oxidative DNA damage. The black and orange lines represent two strands of DNA that is unwounded by DNA helicase during DNA replication. The blue and red lines with arrows represent newly synthesized DNA. Individual proteins are designated as ATR, ATRIP (ATR-interaction protein), TopBP1, 9-1-1 (Rad9-Rad1-Hus1 complex), $\delta / \varepsilon$ (DNA Polymerase $\delta$ or Polymerase $\varepsilon$ ), MCMs (minichromosome maintenance complexes), MRN (Mre11Rad50/Nbs1 complex), FANC complex, APE2, PCNA, Chk1 (Checkpoint kinase 1), Chk2 (Checkpoint kinase 2), and Claspin. The circled " $P$ " in red indicates phosphorylation event. See text for details. a model system for mechanistic studies of the DDR pathways.

\section{DNA damage response pathways in cancer biology}

The DDR pathways include the ATR-Chk1 and ATM-Chk2 checkpoint signaling cascades, coordinating DNA repair with cell cycle progression and apoptosis/senescence (Branzei and Foiani, 2010; Ciccia and Elledge, 2010; Cimprich and Cortez, 2008; Harrison and Haber, 2006). Defects in DDR pathways lead to genomic instability, which is a hallmark of cancer (Hanahan and Weinberg, 2011). A better understanding of the DDR pathways has increased our understanding of cancer development and led to new approaches for cancer therapy.

ATR can be activated by primed single-stranded DNA (ssDNA) from the functional uncoupling of MCM (minichromosome maintenance) helicase and DNA polymerase activities in response to stalled DNA replication forks (Byun et al., 2005; Ciccia and Elledge, 2010; Cimprich and Cortez, 2008). The 5'-3' end resection of DSBs mediated by CtIP nuclease also activates the ATR-Chk1 pathway (Kousholt et al., 2012; Sartori et al., 2007). ATR is recruited to RPA-coated ssDNA via direct interaction between RPA and ATRIP (Zou and Elledge, 2003). ATR activation requires several mediator proteins including its interacting protein ATRIP, TopBP1 and the 9-1-1 (Rad9-Rad1-Hus1) complex (Delacroix et al., 2007; Kumagai et al., 2006; Yan and Michael, 2009b; Zou and Elledge, 2003). Activated ATR phosphorylates multiple substrates including Chk1 (Matsuoka et al., 2007). Chk1 is activated upon phosphorylation, serving as an indicator of ATR activation (Chen and Sanchez, 2004). The ATR-Chk1 pathway can also be activated in response to oxidative stress, inter-strand crosslinks (ICLs), and ultraviolet light (UV) (Ben-Yehoyada et al., 2009; Guo et al., 2000; Willis et al., 2013). In addition, ATR is reported to be autophosphorylated after DNA damage at its Thr 1989 residue (Liu et al., 2011).

In response to DSBs, ATM can be activated by autophosphorylation and dimer dissociation (Bakkenist and Kastan, 2003; Lee and Paull, 2005). This ATM kinase activation requires the Mre11Rad50-Nbs1 (MRN) complex as well as other factors (Paull, 2015). Once activated, ATM kinase phosphorylates a number of substrates including Chk2 and p53 (Rotman and Shiloh, 1999; Smith et al., 2010). Defective ATM kinase is associated with neurodegenera- tive disease ataxia-telangiectasia (Lavin, 2008). Interestingly, the MRN complex is phosphorylated by activated ATM, suggesting the MRN complex serves as both sensor and adaptor for the ATM DDR signaling pathway (Lavin et al., 2015; Paull, 2015). Accumulating evidence suggests that ATM is activated by conformational change during oxidative stress, which is independent of the MRN complex (Guo et al., 2010; Khoronenkova and Dianov, 2015).

Dysfunctions in DDR signaling pathways are implicated in cancer development and characterized in primary patient tumors (Charames and Bapat, 2003; Curtin, 2012). Importantly, multiple DDR proteins are potent therapeutic targets for anti-cancer therapy in preclinical and clinical studies (Fokas et al., 2014; Hosoya and Miyagawa, 2014; Kastan and Bartek, 2004). For example, ATR, Chk1, ATM, and Chk2 are targets for anti-cancer therapy via inhibiting their kinase activities (Antoni et al., 2007; Fokas et al., 2012; Toledo et al., 2011; Weber and Ryan, 2015). Studies of pharmacological inhibitors targeting DDR pathways provide evidence of improved efficacy in chemotherapeutic drugs (Bouwman and Jonkers, 2012). Inhibitors of DDR pathways have also been tested as single agents. Thus, basic research in ATR-Chk1 and ATM-Chk2-mediated DDR pathways will help to better understand tumorigenesis and may identify new anti-cancer targets.

\section{Cell-free Xenopus egg extracts}

Xenopus egg extracts derived from eggs of African clawed frogs have been utilized in studies of DNA replication, DNA repair, and DDR pathways (Costanzo and Gautier, 2004; Karpinka et al., 2015; Kumagai and Dunphy, 2000; Lupardus et al., 2002; Michael et al., 2000; Philpott and Yew, 2008; Raschle et al., 2008; Willis et al., 2013). There are several different types of Xenopus egg extracts: low-speed supernatant (i.e., LSS), high-speed supernatant (i.e., HSS), and nucleoplasmic extracts (i.e., NPE) (Fig. 2). Briefly, Xenopus eggs are crushed by centrifugation at low speed $(20,000 \mathrm{~g})$ to prepare LSS. Then LSS can be further centrifuged at a high-speed $(260,000 \mathrm{~g})$ to prepare HSS. In LSS system, sperm chromatin can be assembled into nuclei, which are further centrifuged into NPE at a high-speed $(260,000 \mathrm{~g})$ (Fig. 2). The approaches of how these different Xenopus egg extracts are made have been described previously (Lebofsky et al., 2009). 
After being added to the LSS, sperm chromatin DNA or bacteriophage lambda DNA can form nuclear envelope and be replicated in a semi-conservative manner, reconstituting an in vitro cell-free DNA replication system that mimics the in vivo DNA replication program in mammalian cells (Blow and Laskey, 1986; Newport, 1987). When DNA damaging agents are used to stress chromatin DNA in LSS system, immunoblotting analysis of proteins of interest (e.g., Chk1 phosphorylation at Ser 344 and ATM phosphorylation at Ser 1981) can dissect molecular mechanisms of DDR pathways (Fig. 3). Chromatin bound fractions can be isolated through sucrose cushion and analyzed via immunoblotting analysis (Fig. 3). Defined DNA structures, such as wild type plasmid DNA or plasmid DNA with an ICL at a defined location, can initiate pre-replication complex assembly in the HSS. However, the DNA replication of plasmid DNA can't be elongated without further addition of the NPE, which contain kinase activities of S-CDK (S-phase cyclindependent kinase) and DDK (Dbf4-dependent kinase Cdc7-Dbf4) (Fig. 3). This unique characteristic of the Xenopus HSS/NPE system uncouples DNA replication initiation from replication elongation. Importantly, plasmid DNA with well-defined damage can be repaired in the HSS/NPE system, and cellular signaling mechanisms can be further dissected (Fig. 3).

The main advantages of the LSS system and the HSS/NPE system are that target proteins can be removed via immunodepletion with specific antibodies and that recombinant wild type or mutant proteins can be added back to depleted egg extracts. Another feature of Xenopus system is that small molecules (e.g., ATM specific inhibitor KU55933) can be added to LSS or HSS to certain concentrations and the roles and mechanisms of these small molecules with respect to DDR pathways can be analyzed (Fig. 3). In addition, Xenopus egg extracts can be aliquoted, frozen and stored in freezers at $-80^{\circ} \mathrm{C}$ for multiple experiments.

\section{Investigating DDR pathways using Xenopusegg extracts}

\section{DNA replication stress}

DNA replication includes initiation, elongation, and termination, and is a fundamental cellular process that ensures accurate duplication of the genetic information stored in the double helix of DNA (O'Donnell et al., 2013; Schekman et al., 1974). Generally defined as the stalling or impediment of DNA replication fork progression, DNA replication stress may result from limited nucleotides, ribonucleotide incorporation, impaired replicative DNA polymerases $(\delta / \varepsilon)$, DNA secondary structures, and fragile sites, as well as oncogene overexpression (Branzei and Foiani, 2010; Mazouzi et al., 2014; Zeman and Cimprich, 2013). Stalled replication forks can be stabilized and lead to cell cycle arrest and late-origin firing inhibition. Replication forks can be restarted downstream of the lesion, leaving a ssDNA gap (Lopes et al., 2006; Yan and Michael, 2009a). The ssDNA gaps then are filled via DNA damage tolerance mechanisms such as lesion bypass or template switching (Chang and Cimprich, 2009). Unresolved stalled replication forks will collapse, resulting in replisome dissociation, nuclease digestion, and broken DNA. The physical structure and protein components of stalled and collapsed replication forks are under intense investigation (Zeman and Cimprich, 2013), and DNA replication stress is now accepted as a hallmark of cancer (Macheret and Halazonetis, 2015).

To study the DNA replication stress response, aphidicolin is widely used to stall DNA replication forks in Xenopus egg extracts. As an efficient inhibitor of DNA polymerase $\delta$ and $\varepsilon$, aphidicolin was utilized in the LSS system to trigger a robust Chk1 phosphorylation at a low concentration (100ng/ $\mathrm{uL}$ ) (Michael et al., 2000; Van et al., 2010). However, Chk1 phosphorylation is compromised when Pol $\alpha$ is inhibited by aphidicolin at a higher concentration $(-300 \mathrm{ng} / \mathrm{uL})$ (Byun et al., 2005). More mechanistic studies have elucidated molecular details of the ATR-Chk1 pathway in DNA replication stress response from various research laboratories (Michael et al., 2000; Trenz et al., 2008; Van et al., 2010; Willis et al., 2012; Yoo et al., 2004). A primed M13-derived ssDNA mimics the ATR-activating structure and activates the ATR-dependent DDR pathway activation in the Xenopus HSS/NPE system (MacDougall et al., 2007). This primed ssDNA structure was further used to demonstrate that the MRN complex recruits TopBP1 for ATR activation (Duursma et al., 2013).

\section{Double-strand breaks (DSBs)}

DSBs are one of the most deleterious types of DNA damage. Failures to detect DSBs and activate DDR signaling pathways for repair will compromise a cell's ability to maintain genomic stability, which is involved in the development of cancer and aging (Jackson and Bartek, 2009). ATM can be activated in response to DSBs and

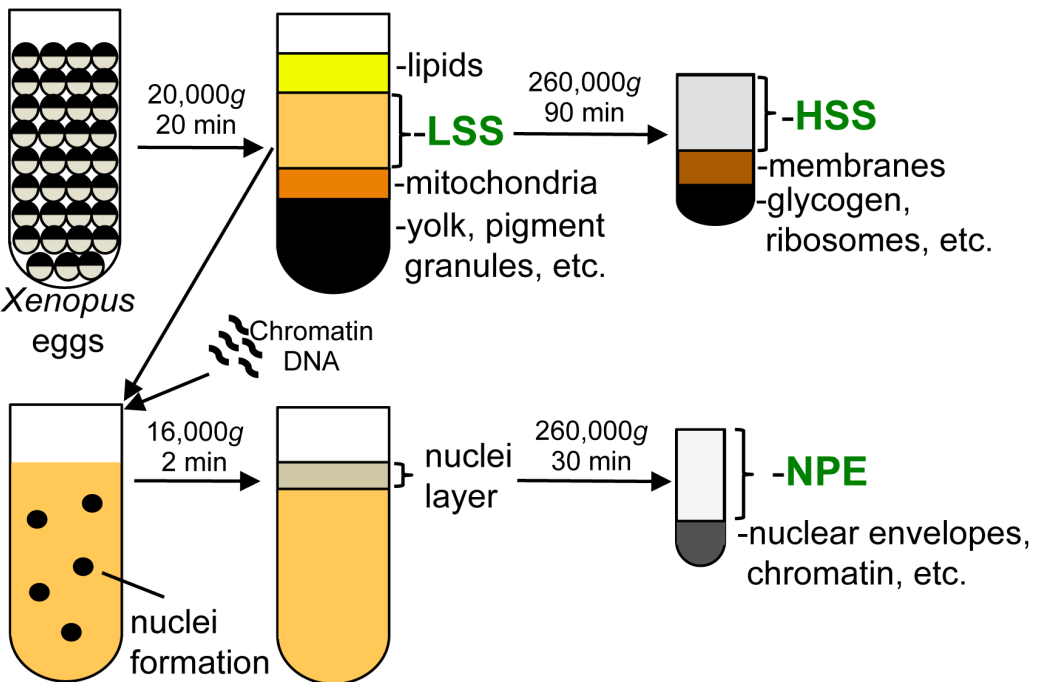

Fig. 2. Diagram of how low-speed supernatant (LSS), highspeed supernatant (HSS) and nucleoplasmic extracts (NPE) are prepared from Xenopus eggs. After PMSG \& HCG stimulation, Xenopus eggs are collected, processed, and centrifuged at $20,000 \mathrm{~g}$ to prepare the LSS fraction, while the top lipids layer and bottom mitochondria and yolk as well as pigment granules are discarded. The LSS can be further centrifuged with a speed of $260,000 \mathrm{~g}$ to separate the HSS from membrane fractions and glycogen as well as ribosomes. Sperm chromatin DNA can be added to the LSS, which form nuclear envelop. The nuclei formed from LSS are centrifuged and collected from the top layer, as indicated. The nuclei fraction will be spun again with a speed of $260,000 \mathrm{~g}$ to separate to distinguish the NPE fraction from nuclear envelopes and chromatin. Details of how LSS, HSS, and NPE are prepared can be found from previously studies (Lebofsky et al., 2009; Willis et al., 2012). 


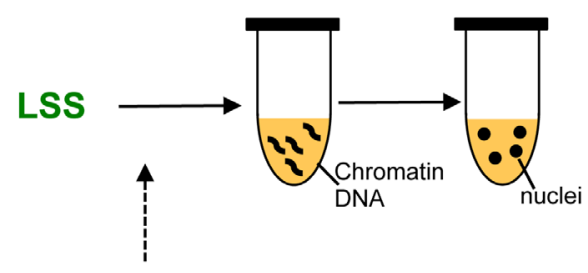

$\checkmark$ DNA damaging agents (e.g., $\mathrm{H}_{2} \mathrm{O}_{2}$ )

$\checkmark$ Immunodepletion of target proteins

$\checkmark$ Addition of recombinant proteins

$\checkmark$ Small molecules or compounds

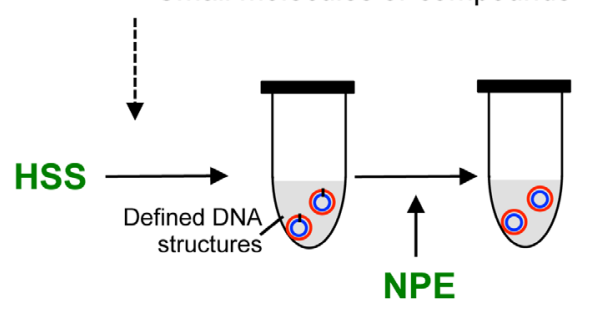

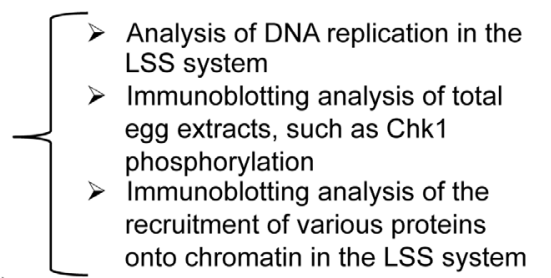

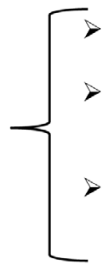

DNA repair analysis in the HSS system via gel electrophoresis

Immunoblotting analysis of total egg extracts for cellular signaling molecules

Immunoblotting analysis of the recruitment of various proteins onto DNA in the HSS system
Fig. 3. The Xenopus LSS or HSS/NPE system is utilized to study DDR pathways. LSS, Low-speed supernatant; HSS, high-speed supernatant; NPE, nucleoplasmic extracts. Two approaches are utilized in Xenopus system: (I) Chromatin DNA can be added to the LSS, in which chromatin is surrounded with nuclear envelope into nuclei and chromatin DNA can be replicated. DNA damaging agents such as hydrogen peroxide can be added to damage chromatin DNA. (II) Plasmid DNA with defined DNA damage such as a single ICL at a defined location can be added to the HSS, which is subsequently supplemented with the NPE. In this HSS/NPE system, defined DNA structures can be replicated and repaired. In both approaches, customized antibody-based immunodepletion can remove target proteins from the LSS or HSS, which can be added with wild type or mutant recombinant proteins. In addition, small molecules or compounds can be easily added to the LSS or HSS/NPE systems to perform dose-dependent assays. See text for details. phosphorylates hundreds of substrates including Chk2 (Bakkenist and Kastan, 2003; Daniel et al., 2012). The ATM-Chk2-mediated DDR pathway was suggested as an anti-cancer barrier in early human tumorigenesis (Bartkova et al., 2005). The ATR-Chk1mediated DDR pathway can also be activated after DSB end resection (Shiotani and Zou, 2009).

Restriction enzymes have been used to cleave circular DNA into linear version for studies of DSB-induced DDR pathways in Xenopus egg extracts. DSB-containing chromatin DNA can be generated by the addition of restriction enzyme (in particular, EcoRI and PfIMI) to LSS system, triggering an ATR-mediated checkpoint response (Ramirez-Lugo et al., 2011). EcoRl-treated chromatin DNA can also trigger ATM and Nbs1 phosphorylation in the LSS system (You et al., 2005). After Haelll treatment, DSB-containing plasmid pBR322 triggers ATM-dependent checkpoint signaling that inhibits chromosomal DNA replication (Costanzo et al., 2000). After generation by digestion with restriction enzymes or by PCR using pBluescript as template, linear DNA fragments with different lengths were used in the Xenopus HSS system to demonstrate that ATM activation by DSBs requires at least $\sim 200$ bps of linear dsDNA (double-stranded DNA) and the binding of ATM to dsDNA region flanking DSB ends (You et al., 2007).

DSBs can also be generated after exposure to ionizing radiation or chemotherapeutic drugs. Chromatin DNA can be damaged by $\gamma$-radiation to generate DSBs, which can be added to XenopusLSS, triggering the ATM-mediated DDR pathway (Costanzo and Gautier, 2004). Exposure to etoposide, an inhibitor of topoisomerase II, can induce an ATR-mediated, but ATM-independent, DDR pathway activation that prevents DNA replication initiation in Xenopus LSS system (Costanzo et al., 2003; Tsuji et al., 2008). Camptothecin, an inhibitor of topoisomerase I, was used to generate DSBs to study the ATM/ATR-dependent replication restart mechanism in Xenopus (Trenz et al., 2006). In addition, a DNADSB-mimic structure named AT70, an annealed complex of two oligonucleotides poly-(dA)70 and poly-(dT)70, was initially characterized in the Dunphy lab and utilized widely to investigate ATM- and ATR-mediated DDR pathways in Xenopus (Jazayeri et al., 2008; Kumagai and Dunphy, 2000; Yan et al., 2006).

\section{Oxidative stress and oxidative DNA damage}

Oxidative stress is defined as an imbalance between the production of reactive oxygen species (ROS) and the capacity of antioxidant defenses (Jones, 2006; Sies, 1997). ROS include hydrogen peroxide and hydroxyl radicals and can be generated from cellular metabolism, such as oxidative phosphorylation in mitochondria, and exogenous sources, such as chemotherapeutic agents (Dizdaroglu, 2012; Riley, 1994). Oxidative stress can induce different forms of DNA damage including base damage, such as 8-oxo-7,8-dihydroguanine (8-oxo-G) and apurinic/apyrimidinic (AP) sites (Cadet et al., 2012; Lindahl, 1993). Oxidative DNA damage is repaired primarily by base excision repair (BER) while other repair pathways, such as nucleotide excision repair (NER), nucleotide incision repair (NIR), and mismatch repair (MMR), are backup mechanisms (Berquist and Wilson, 2012; Yan et al., 2014). Oxidative stress has been implicated in the pathogeneses of cancer, aging, and neurodegenerative diseases (Richardson et al., 2015).

Chromatin DNA can be damaged by hydrogen peroxide to generate oxidative DNA damage, which triggers the activation of ATR- and ATM-mediated DDR pathways in Xenopus LSS system (Willis et al., 2013). Notably, a base excision repair protein APE2 was demonstrated to play an essential but previously uncharacterized role in the hydrogen peroxide-induced ATR-Chk1 pathway activation (Willis et al., 2013). This study led to a more general conception that various DNA repair proteins interplay functionally with DDR pathways in oxidative stress (Yan et al., 2014).

\section{Inter-strand crosslinks (ICLs)}

ICLs are extremely cytotoxic lesions because irreparable ICLs prevent DNA replication and transcription programs, thereby threatening genome stability (McVey, 2010; Wang et al., 2008). Although DNA crosslinking agents such as mitomycin C (MMC) are widely used in chemotherapy, tumor cells also acquire resistance to such agents (Long and Walter, 2012). The chemotherapeutic drug MMC was used to generate crosslinks in chromatin DNA, which can activate the ATR-Chk1 DDR pathway in a Xenopus LSS system (Yan and Willis, 2013). This MMC-induced system has been utilized to elucidate the requirements of nuclear import of TopBP1 
and FANC complex for DDR pathway activation (Bai et al., 2014; Wang et al., 2008). Our understanding of ICL repair and signaling pathways has been advanced using a defined plasmid-based ICL in the Xenopus HSS/NPE system, in which DNA replication of plasmid DNA is initiated in the HSS first, and subsequently elongated once NPE is added (Figs. 2 and 3) (Ben-Yehoyada et al., 2009; Raschle et al., 2008). ICLs activate the DDR pathway, which requires the Fanconi anemia (FANC) complex (Ben-Yehoyada et al., 2009; Knipscheer et al., 2009).

\section{Role of TLS polymerases in the ATR-Chk1 DDR pathway}

ATR is recruited to RPA-coated SsDNA via direct interaction of ATRIP with RPA, though it is currently unknown whether TopBP1's
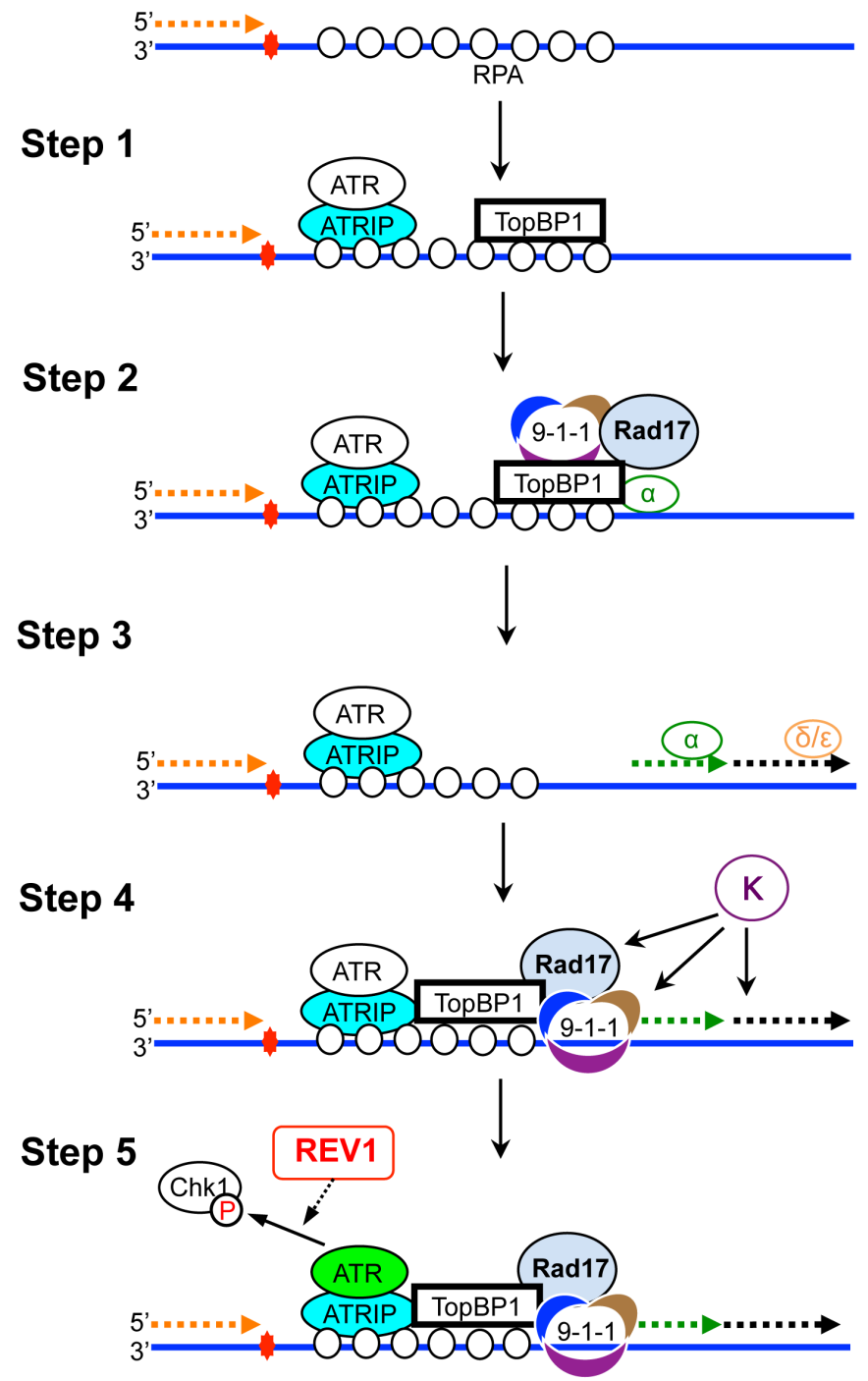

Fig. 4. A model for the role of TLS polymerases Pol $\kappa$ and REV1 in the ATR-Chk1 DDR pathway. Pol $\kappa$ has three mechanisms: primer synthesis, 9-1-1 recruitment, and Rad17 stabilization. REV1 is dispensable for the recruitment of ATR, ATRIP, TopBP1, 9-1-1, and RPA onto stalled forks, but is important for Chk1 phosphorylation by activated ATR. Please see the text for details. recruitment to stalled replication forks requires direct TopBP1-RPA association (Step 1, Fig. 4). A model is proposed for how checkpoint activation on the leading strand is coupled to replication restart in response to stalled replication forks, in which TopBP1 recruits Pol $\alpha$, and then TopBP1 and Pol $\alpha$ work together to recruit the 9-1-1 complex to stalled replication forks in Xenopus egg extracts (Step 2, Fig. 4) (Yan and Michael, 2009a; Yan and Michael, 2009b). Moreover, primer synthesis is initiated by Pol $\alpha$ and continued by Pol $\delta$ and $\mathrm{Pol} \varepsilon$ on stalled replication forks, which contributes to checkpoint activation in Xenopus egg extracts (Step 3, Fig. 4) (Van et al., 2010). TopBP1 bridges ATR-ATRIP with the 9-1-1 complex via direction protein-protein interactions, while the 9-1-1 complex is preferentially recruited to the ssDNA/dsDNA junction (Step 4, Fig. 4). Lastly, ATR is directly activated by TopBP1, and Chk1 is then phosphorylated by activated ATR (Step 5, Fig. 4).

It's significant to determine how TLS polymerases and DDR pathways regulate each other. Several recent studies have shed lights on the role of TLS polymerases for DDR pathway activation. Notably, TLS polymerase Pol $\mathrm{k}$ is required for the primer synthesis, the recruitment of the 9-1-1 complex onto stalled replication forks, and subsequent activation of the ATR-Chk1 DDR pathway in both Xenopus egg extracts and human cells lines (Step 4, Fig. 4) (Betous et al., 2013). Consistent with this observation, Pol $\mathrm{K}$ depletion facilitates temozolomide (TMZ)-induced ubiquitination and proteasome-mediated degradation of Rad17 and severely compromises ATR-Chk1 DDR pathway activation in human glioblastoma cell lines (Step 4, Fig. 4) (Wang et al., 2016). These findings suggest that TLS polymerases play a previously uncharacterized role in ATR-Chk1 DDR pathway via its catalytic and non-catalytic functions. Importantly, anotherTLS polymerase REV1 is required for the activation of in the ATR-Chk1 DDR pathway but is dispensable for the recruitment of ATR, ATRIP, TopBP1, the 9-1-1 complex, and RPA onto stalled replication forks and ICLs, suggesting a role of REV1 in the downstream of ATR activation but before Chk1 phosphorylation (Step 5, Fig. 4) (DeStephanis et al., 2015). Thus, TLS polymerases Pol $\mathrm{K}$ and REV1 are involved in a positive regulation for the DDR pathway. It remains to be determined whether other TLS polymerases also regulate the DDR pathways. Defects in TLS polymerases have been implicated in human tumorigenesis and inhibitors to TLS polymerases such as Pol $\mathrm{k}$ are being developed (Curtin, 2012; Yamanaka et al., 2012).

\section{Future directions}

One advantage of the Xenopus egg extracts system is the ability to study DDR pathways through removing a target protein via antibody-based immunodepletion procedure and adding back recombinant wild type or mutant protein. These antibody-based approaches in Xenopustypically require large amounts of customized antiserum (i.e., in the scale of milliliters), which limits the wide use of this cell-free model system. There is a great demand from the Xenopuscommunity to establish a national or international resource center providing antisera targeting specific proteins of interest.

CRISPR/Cas9-mediated targeted gene editing has been successfully utilized in Xenopus laevis and Xenopus tropicalis (Nakayama et al., 2013; Wang et al., 2015). It will be interesting to determine whether egg extracts from wild type and CRISPR/ Cas9-edited Xenopus laevis can be compared and analyzed to study DDR pathways. One possible caveat of this CRISPR/ 
Cas9-mediated knock-out approach is that it may not be feasible to generate viable gene-edited frogs if protein of interest is essential for early embryogenesis. Recently a CRISPR/Cas9-mediated knock-in technology was reported in Xenopus tropicalis (Shi et al., 2015). These CRISPR/Cas9-mediated knock-out and knock-in techniques would be applied to investigate the DDR pathways in response to environmental toxins or chemotherapeutic drugs during early embryogenesis and development. Nevertheless, CRISPR/ Cas9-mediated gene editing in frogs may offer complementary approach for mechanistic studies of DDR pathways in addition to the cell-free Xenopus egg extract system.

Proteomics and mass spectrometry-based approaches can be incorporated into the Xenopus system. Proteomics-based analysis has been used to reveal a switch in CDK1-associated proteins upon M-phase exit during the Xenopus laevis oocyte to embryo transition (Marteil et al., 2012). This kind of systematic analysis can be applied to DDR pathway research in Xenopus egg extracts too. A recent report described a new technique called chromatin mass spectrometry (CHROMASS) to study protein recruitment dynamics on psoralen-damaged chromatin in Xenopus egg extracts (Raschle et al., 2015). With this CHROMASS procedure, systematic analysis of assembly and disassembly of DNA repair proteins on ICL-damaged chromatin in Xenopus becomes feasible. It remains to be determined whether the proteomics and mass-spectrometrybased approaches will be expanded to study other types of DNA damage and stressful conditions.

\section{Acknowledgements}

The Yan lab is supported in part by grants from NIH/NIGMS (R15 GM101571 and R15 GM114713). The Richardson lab is supported in part by $\mathrm{NIH} / \mathrm{NCl}$ (R01 CA100159). We apologize to colleagues whose findings were not cited in this review due to space limitations.

\section{References}

ANTONI, L., SODHA, N., COLLINS, I. and GARRETT, M.D. (2007). CHK2 kinase: cancer susceptibility and cancer therapy - two sides of the same coin? Nat Rev Cancer 7: 925-936.

BAI, L., MICHAEL, W.M. and YAN, S. (2014). Importin beta-dependent nuclear import of TopBP1 in ATR-Chk1 checkpoint in Xenopusegg extracts. Cell Signal26: 857-867.

BAKKENIST, C.J. and KASTAN, M.B. (2003). DNA damage activates ATM through intermolecular autophosphorylation and dimer dissociation. Nature 421: 499-506.

BARTKOVA, J., HOREJSÍ, Z., KOED, K., KRÄMER, A., TORT, F., ZIEGER, K., GULDBERG, P., SEHESTED, M., NESLAND, J., LUKAS, C., ORNTOFT, T., LUKAS, J. and BARTEK, J. (2005). DNA damage response as a candidate anti-cancer barrier in early human tumorigenesis. Nature 434: 864-870.

BEN-YEHOYADA, M., WANG, L.C., KOZEKOV, I.D., RIZZO, C.J., GOTTESMAN, M.E. and GAUTIER, J. (2009). Checkpoint signaling from a single DNA interstrand crosslink. Mol Cell 35: 704-715.

BERQUIST, B.R. and WILSON, $3^{\text {RD }}$, D.M. (2012). Pathways for repairing and tolerating the spectrum of oxidative DNA lesions. Cancer Lett 327: 61-72.

BETOUS, R., PILLAIRE, M.J., PIERINI, L., VAN DER LAAN, S., RECOLIN, B., OHL-SEGUY, E., GUO, C., NIIMI, N., GRUZ, P., NOHMI, T., FRIEDBERG, E., CAZAUX, C., MAIORANO, D. and J.S. HOFFMANN. (2013). DNA polymerase kappa-dependent DNA synthesis at stalled replication forks is important for $\mathrm{CHK} 1$ activation. EMBO J 32: 2172-85.

BLOW, J.J., DILWORTH, S.M., DINGWALL, C., MILLS, A.D. and LASKEY, R.A. (1987). Chromosome replication in cell-free systems from Xenopus eggs. Philos Trans R Soc Lond B Biol Sci 317: 483-494.

BLOW, J.J. and Laskey, R.A. (1986). Initiation of DNA replication in nuclei and purified DNA by a cell-free extract of Xenopus eggs. Cell 47: 577-587.

BOUWMAN, P. and JONKERS, J. (2012). The effects of deregulated DNA damage signalling on cancer chemotherapy response and resistance. Nat Rev Cancer 12: $587-598$.

BRANZEI, D. and FOIANI, M. (2010). Maintaining genome stability at the replication fork. Nat Rev Mol Cell Biol 11: 208-219.

BYUN, T.S., PACEK, M., YEE, M.C., WALTER, J.C. and CIMPRICH, K.A. (2005). Functional uncoupling of MCM helicase and DNA polymerase activities activates the ATR-dependent checkpoint. Genes Dev 19: 1040-1052.

CADET, J., RAVANAT, J.L., TAVERNAPORRO, M., MENONI, H. and ANGELOV, D. (2012). Oxidatively generated complex DNA damage: tandem and clustered lesions. Cancer Lett 327: 5-15.

CHANG, D.J. and CIMPRICH, K.A. (2009). DNA damage tolerance: when it's OK to make mistakes. Nat Chem Biol 5: 82-90.

CHARAMES, G.S. and BAPAT, B. (2003). Genomic instability and cancer. Curr Mol Med 3: 589-596.

CHEN, Y. and SANCHEZ, Y. (2004). Chk1 in the DNA damage response: conserved roles from yeasts to mammals. DNA Repair (Amst) 3: 1025-1032.

CICCIA, A. and ELLEDGE, S.J. (2010). The DNA damage response: making it safe to play with knives. Mol Cell 40: 179-204.

CIMPRICH, K.A. and CORTEZ, D. (2008). ATR: an essential regulator of genome integrity. Nat Rev Mol Cell Biol 9: 616-627.

COSTANZO, V. and GAUTIER, J. (2004). Xenopus cell-free extracts to study DNA damage checkpoints. Methods Mol Biol 241: 255-267.

COSTANZO, V., ROBERTSON, K., YING, C.Y., KIM, E., AVVEDIMENTO, E., GOTTESMAN, M., GRIECO, D. and GAUTIER, J. (2000). Reconstitution of an ATMdependent checkpoint that inhibits chromosomal DNA replication following DNA damage. Mol Cell 6: 649-659.

COSTANZO, V., SHECHTER, D., LUPARDUS, P.J., CIMPRICH, K.A., GOTTESMAN, M. and GAUTIER, J. (2003). An ATR- and Cdc7-dependent DNA damage checkpoint that inhibits initiation of DNA replication. Mol Cell 11: 203-213.

CURTIN, N.J. (2012). DNA repair dysregulation from cancer driver to therapeutic target. Nat Rev Cancer. 12: 801-817.

DANIEL, J.A., PELLEGRINI, M., LEE, B.S., GUO, Z., FILSUF, D., BELKINA, N.V., YOU, Z., PAULL, T.T., SLECKMAN, B.P., FEIGENBAUM, L. and NUSSENZWEIG, A. (2012). Loss of ATM kinase activity leads to embryonic lethality in mice. J Cell Biol 198: 295-304.

DELACROIX, S., WAGNER, J.M., KOBAYASHI, M., YAMAMOTO, K. and KARNITZ, L.M. (2007). The Rad9-Hus1-Rad1 (9-1-1) clamp activates checkpoint signaling via TopBP1. Genes Dev 21: 1472-1477.

DESTEPHANIS, D., MCLEOD, M. and YAN, S. (2015). REV1 is important for the ATR-Chk1 DNA damage response pathway in Xenopus egg extracts. Biochem Biophys Res Commun 460: 609-615.

DIZDAROGLU, M. (2012). Oxidatively induced DNA damage: mechanisms, repair and disease. Cancer Lett 327: 26-47.

DUURSMA, A.M., DRISCOLL, R., ELIAS, J.E. and CIMPRICH, K.A. (2013). A role for the MRN complex in ATR activation via TOPBP1 recruitment. Mol Cell50: 116-122.

FOKAS, E., PREVO, R., HAMMOND, E.M., T.B. BRUNNER, T.B., MCKENNA, W.G., and MUSCHEL, R.J. (2014). Targeting ATR in DNA damage response and cancer therapeutics. Cancer Treat Rev 40: 109-117.

FOKAS, E., PREVO, R., POLLARD, J.R., REAPER, P.M., CHARLTON, P.A., CORNELISSEN, B., VALLIS, K.A., HAMMOND, E.M., OLCINA, M.M., GILLIES MCKENNA, W., MUSCHEL, R.J. and BRUNNER, T.B. (2012). Targeting ATR in vivo using the novel inhibitor VE-822 results in selective sensitization of pancreatic tumors to radiation. Cell Death Dis 3:e441.

GANDINI ATTARDI, D., MARTINI, G., MATTOCCIA, E. and TOCCHINI-VALENTINI, G.P. (1976). Effect of Xenopus laevis oocyte extract on supercoiled simian virus 40 DNA: formation of complex DNA. Proc Natl Acad Sci USA 73: 554-558.

GUO, Z., KOZLOV, S., LAVIN, M.F., PERSON, M.D. and PAULL, T.T. (2010). ATM activation by oxidative stress. Science 330: 517-521.

GUO, Z., KUMAGAI, A., WANG, S.X. and DUNPHY, W.G. (2000). Requirement for Atr in phosphorylation of Chk1 and cell cycle regulation in response to DNA replication blocks and UV-damaged DNA in Xenopus egg extracts. Genes Dev 14:2745-2756.

HANAHAN, D. and WEINBERG, R.A. (2011). Hallmarks of cancer: the next generation. Cell 144: 646-674.

HARRISON, J.C., and Haber, J.E. (2006). Surviving the breakup: the DNA damage checkpoint. Annu Rev Genet 40: 209-235. 
HO, T.V. and SCHARER, O.D. (2010). Translesion DNA synthesis polymerases in DNA interstrand crosslink repair. Environ Mol Mutagen 51: 552-566.

HOSOYA, N., and MIYAGAWA, K. (2014). Targeting DNA damage response in cancer therapy. Cancer Sci 105: 370-388.

JACKSON, S.P. and BARTEK, J. (2009). The DNA-damage response in human biology and disease. Nature 461: 1071-1078.

JAZAYERI, A., BALESTRINI, A., GARNER, E., HABER, J.E. and COSTANZO, V. (2008). Mre11-Rad50-Nbs1-dependent processing of DNA breaks generates oligonucleotides that stimulate ATM activity. EMBO J 27: 1953-1962.

JONES, D.P. 2006. Redefining oxidative stress. Antioxid Redox Signal. 8: 1865-1879.

KARPINKA, J.B., FORTRIEDE, J.D., BURNS, K.A., JAMES-ZORN, C., PONFERRADA, V.G., LEE, J., KARIMI, K., ZORN, A.M. and VIZE, P.D. (2015). Xenbase, the Xenopus model organism database; new virtualized system, data types and genomes. Nucleic Acids Res 43:D756-763.

KASTAN, M.S. and BARTEK, J. (2004). Cell-cycle checkpoints and cancer. Nature 432: 316-323

KHORONENKOVA, S.V. and DIANOV, G.L. (2015). ATM prevents DSB formation by coordinating SSB repair and cell cycle progression. Proc Natl Acad Sci USA 112: 3997-4002.

KNIPSCHEER, P., RASCHLE, M., SMOGORZEWSKA, A., ENOIU, M., HO, T.V., SCHARER, O.D., ELLEDGE, S.J. and WALTER, J.C. (2009). The Fanconi anemia pathway promotes replication-dependent DNA interstrand cross-link repair. Science 326: 1698-1701.

KOUSHOLT, A.N., FUGGER, K., HOFFMANN, S., LARSEN, B.D., MENZEL, T., SARTORI, A.A. and SORENSEN, C.S. (2012). CtIP-dependent DNA resection is required for DNA damage checkpoint maintenance but not initiation. $J$ Cell Biol 197: 869-876.

KUMAGAI, A., and DUNPHY, W.G. (2000). Claspin, a novel protein required for the activation of Chk1 during a DNA replication checkpoint response in Xenopus egg extracts. Mol Cell 6: 839-849.

KUMAGAI, A., LEE, J., YOO, H.Y. and DUNPHY, W.G. (2006). TopBP1 activates the ATR-ATRIP complex. Cell 124: 943-955.

LASKEY, R.A., MILLS, A.D. and MORRIS, N.R. (1977). Assembly of SV40 chromatin in a cell-free system from Xenopus eggs. Cell 10: 237-243.

LAVIN, M.F. (2008). Ataxia-telangiectasia: from a rare disorder to a paradigm for cell signalling and cancer. Nat Rev Mol Cell Biol 9: 759-769.

LAVIN, M.F., KOZLOV, S., GATEI, M. and KIJAS, A.W. (2015). ATM-Dependent Phosphorylation of All Three Members of the MRN Complex: From Sensor to Adaptor. Biomolecules 5: 2877-2902.

LEBOFSKY, R., TAKAHASHI, T. and WALTER, J.C. (2009). DNA replication in nucleusfree Xenopus egg extracts. Methods Mol Biol 521: 229-252.

LEE, J.H. and PAULL, T.T. (2005). ATM activation by DNA double-strand breaks through the Mre11-Rad50-Nbs1 complex. Science 308: 551-554.

LINDAHL, T. 1993. Instability and decay of the primary structure of DNA. Nature 362: 709-715

LIU, S., SHIOTANI, B., LAHIRI, M., MARECHAL, A., TSE, A., LEUNG, C.C., GLOVER, J.N., YANG, X.H. and ZOU, L. (2011). ATR autophosphorylation as a molecular switch for checkpoint activation. Mol Cell 43: 192-202.

LONG, D.T. and WALTER, J.C. (2012). A novel function for BRCA1 in crosslink repair. Mol Cell 46: 111-112.

LOPES, M., FOIANI, M. and SOGO, J.M. (2006). Multiple mechanisms control chromosome integrity after replication fork uncoupling and restart at irreparable UV lesions. Mol Cell 21: 15-27.

LUPARDUS, P.J., BYUN, T., YEE, M.C., HEKMAT-NEJAD, M. and CIMPRICH, K.A. (2002). A requirement for replication in activation of the ATR-dependent DNA damage checkpoint. Genes Dev 16: 2327-2332.

MACDOUGALL, C.A., BYUN, T.S., VAN, C., YEE, M.C. and CIMPRICH, K.A. (2007). The structural determinants of checkpoint activation. Genes Dev 21: 898-903.

MACHERET, M. and HALAZONETIS, T.D. (2015). DNA replication stress as a hallmark of cancer. Annu Rev Pathol 10: 425-448.

MARTEIL, G., GAGNÉ, J.P., BORSUK, E., RICHARD-PARPAILLON, L., POIRIER, G.G., and KUBIAK, J.Z. (2012). Proteomics reveals a switch in CDK1-associated proteins upon M-phase exit during the Xenopus laevis oocyte to embryo transition. Int J Biochem Cell Biol 44: 53-64.
MATSUOKA, S., BALLIF, B.A., SMOGORZEWSKA, A., MCDONALD, 3RD, E.R. HUROV, K.E., LUO, J., BAKALARSKI, C.E., ZHAO, Z., SOLIMINI, N., LERENTHAL, Y., SHILOH, Y., GYGI, S.P. and ELLEDGE, S.J. (2007). ATM and ATR substrate analysis reveals extensive protein networks responsive to DNA damage. Science 316: 1160-1166.

MAZOUZI, A., VELIMEZI, G. and LOIZOU, J.I. (2014). DNA replication stress: causes, resolution and disease. Exp Cell Res 329: 85-93.

MCVEY, M. 2010. Strategies for DNA interstrand crosslink repair: insights from worms, flies, frogs, and slime molds. Environ Mol Mutagen 51: 646-658.

MICHAEL, W.M., OTT, J., FANNING, E. and NEWPORT, J. (2000). Activation of the DNA Replication Checkpoint Through RNA Synthesis by Primase. Science 289: 2133-2137.

NAKAYAMA, T., FISH, M.B., FISHER, M., OOMEN-HAJAGOS, J., THOMSEN, G.H. and GRAINGER, R.M. (2013). Simple and efficient CRISPR/Cas9-mediated targeted mutagenesis in Xenopus tropicalis. Genesis 51: 835-843.

O'DONNELL, M., LANGSTON, L. and STILLMAN, B. (2013). Principles and concepts of DNA replication in bacteria, archaea, and eukarya. Cold Spring Harb Perspect Biol 5: a010108.

NEWPORT, J. (1987). Nuclear reconstitution In vitro: stages of assembly around protein-free DNA. Cell 48: 205-217.

PAULL, T.T. (2015). Mechanisms of ATM Activation. Annu Rev Biochem 84: 711-738.

PHILPOTT, A. and YEW, P.R. (2008). The Xenopus cell cycle: an overview. Mol Biotechnol 39: 9-19.

RAMIREZ-LUGO, J.S., YOO, H.Y., YOON, S.J. and DUNPHY, W.G. (2011). CtIP interacts with TopBP1 and Nbs1 in the response to double-stranded DNA breaks (DSBs) in Xenopus egg extracts. Cell Cycle 10: 469-480.

RASCHLE, M., KNIPSCHEER, P., ENOIU, M., ANGELOV, T., SUN, J., GRIFFITH, J.D., ELLENBERGER, T.E., SCHARER, O.D. and WALTER, J.C. (2008). Mechanism of replication-coupled DNA interstrand crosslink repair. Cell 134: 969-980.

RASCHLE, M., SMEENK, G., HANSEN, R.K., TEMU, T., OKA, Y., HEIN, M.Y., NAGARAJ, N., LONG, D.T., WALTER, J.C., HOFMANN, K., STORCHOVA, Z., COX, J., BEKKER-JENSEN, S., MAILAND, N. and MANN, M. (2015). Proteomics reveals dynamic assembly of repair complexes during bypass of DNA cross-links. Science 348: 1253671

RICHARDSON, C., YAN, S. and VESTAL, C.G. (2015). Oxidative Stress, Bone Marrow Failure, and Genome Instability in Hematopoietic Stem Cells. Int J Mol Sci 16: 2366-2385

RILEY, P.A. (1994). Free radicals in biology: oxidative stress and the effects of ionizing radiation. Inter J Radiat Biol 65: 27-33.

ROTMAN, G. and SHILOH, Y. (1999). ATM: a mediator of multiple responses to genotoxic stress. Oncogene 18: 6135-6144.

SARTORI, A.A., LUKAS, C., COATES, J., MISTRIK, M., FU, S., BARTEK, J., BAER, R., LUKAS, J. and JACKSON, S.P. (2007). Human CtIP promotes DNA end resection. Nature 450: 509-514.

SCHEKMAN, R., A. WEINER, AND A. KORNBERG. 1974. Multienzyme systems of DNA replication. Science 186: 987-993.

SHI, Z., WANG, F., CUI, Y., LIU, Z., GUO, X., ZHANG, Y., DENG, Y., ZHAO, H., and CHEN, Y. (2015). Heritable CRISPR/Cas9-mediated targeted integration in Xenopus tropicalis. FASEB J. 29: 4914-4923.

SHIOTANI, B. and ZOU, L. (2009). Single-stranded DNA orchestrates an ATM-to-ATR switch at DNA breaks. Mol Cell 33: 547-558

SIES, H. (1997). Oxidative stress: oxidants and antioxidants. Exp Physio/82: 291-295.

SMITH, J., THO, L.M., XU, N. and GILLESPIE, D.A. (2010). The ATM-Chk2 and ATRChk1 pathways in DNA damage signaling and cancer. Adv Cancer Res 108:73-112.

TOLEDO, L.I., MURGA, M. and FERNANDEZ-CAPETILLO, O. (2011). Targeting ATR and Chk1 kinases for cancer treatment: a new model for new (and old) drugs. $\mathrm{Mol}$ Oncol 5: 368-373.

TRENZ, K., ERRICO, A. and COSTANZO, V. (2008). PIx1 is required for chromosomal DNA replication under stressful conditions. EMBO J 27: 876-885.

TRENZ, K., SMITH, E., SMITH, S. andCOSTANZO, V. (2006). ATM and ATR promote Mre11 dependent restart of collapsed replication forks and prevent accumulation of DNA breaks. EMBO J 25: 1764-1774.

TSUJI, T., LAU, E., CHIANG, G.G. and JIANG, W. (2008). The role of Dbf4/Drf1dependent kinase Cdc7 in DNA-damage checkpoint control. Mol Cel/32: 862-869. 


\section{S. Cupello et al.}

VAN, C., YAN, S., MICHAEL, W.M., WAGA, S. and CIMPRICH, K.A. (2010). Continued primer synthesis at stalled replication forks contributes to checkpoint activation. $J$ Cell Biol 189: 233-246.

WANG, F., SHI, Z., CUI, Y., GUO, X., SHI, Y.B. and CHEN, Y. (2015). Targeted gene disruption in Xenopus laevis using CRISPR/Cas9. Cell Biosci 5: 15.

WANG, H., PENG, C., CHEN, Z., WANG, S., WANG, H.W., QIU, W., ZHAO, L., XU, R., LUO, H., CHEN, Y., CHEN, D., YOU, Y. and LIU, N. (2016). The error-prone DNA polymerase kappa promotes temozolomide resistance in glioblastoma through Rad17-dependent activation of ATR-Chk1 signaling. Cancer Res. 76. DOI: 10.1158/0008-5472.CAN-15-1884

WANG, L.C., STONE, S., HOATLIN, M.E. and GAUTIER, J. (2008). Fanconi anemia proteins stabilize replication forks. DNA Repair. 7: 1973-1981.

WEBER, A.M. and RYAN, A.J. (2015). ATM and ATR as therapeutic targets in cancer. Pharmacol Ther 149: 124-138.

WILLIAMS, H.L., GOTTESMAN, M.E. and GAUTIER, J. (2012). Replication-independent repair of DNA interstrand crosslinks. Mol Cell 47: 140-147.

WILLIS, J., DESTEPHANIS, D., PATEL, Y., GOWDA, V. and YAN, S. (2012). Study of the DNA damage checkpoint using Xenopus egg extracts. $J$ Vis Exp. e4449.

WILLIS, J., PATEL, Y., LENTZ, B.L. and YAN, S. (2013). APE2 is required for ATRChk1 checkpoint activation in response to oxidative stress. Proc Natl Acad Sci USA. 110: 10592-10597.

YAMANAKA, K., DORJSUREN, D., EOFF, R.L., EGLI, M., MALONEY, D.J., JADHAV, A., SIMEONOV, A. and LLOYD, R.S. (2012). Acomprehensive strategy to discover inhibitors of the translesion synthesis DNA polymerase kappa. PLoSOne. 7: e45032.

YAN, S., LINDSAY, H.D. and MICHAEL, W.M. (2006). Direct requirement for Xmus101 in ATR-mediated phosphorylation of Claspin bound Chk1 during checkpoint signaling. J Cell Biol 173: 181-186.

YAN, S. and MICHAEL, W.M. (2009a). TopBP1 and DNA polymerase alpha-mediated recruitment of the 9-1-1 complex to stalled replication forks: implications for a replication restart-based mechanism for ATR checkpoint activation. Cell Cycle 8: $2877-2884$

YAN, S. and MICHAEL, W.M. (2009b). TopBP1 and DNA polymerase-alpha directly recruit the 9-1-1 complex to stalled DNA replication forks. J Cell Biol 184: 793-804.

YAN, S., SORRELL, M. and BERMAN, Z. (2014). Functional interplay between ATM/ ATR-mediated DNA damage response and DNA repair pathways in oxidative stress. Cell Mol Life Sci 71: 3951-3967.

YAN, S. and WILLIS, J. (2013). WD40-repeat protein WDR18 collaborates with TopBP1 to facilitate DNA damage checkpoint signaling. Biochem Biophys Res Commun 431: 466-471.

YOO, H.Y., KUMAGAI, A., SHEVCHENKO, A. and DUNPHY, W.G. (2004). Adaptation of a DNA replication checkpoint response depends upon inactivation of Claspin by the Polo-like kinase. Cell 117: 575-588.

YOU, Z., BAILIS, J.M., JOHNSON, S.A., DILWORTH, S.M. and HUNTER, T. (2007) Rapid activation of ATM on DNA flanking double-strand breaks. Nat Cell Biol 9 1311-1318.

YOU, Z., CHAHWAN, C., BAILIS, J., HUNTER, T. and RUSSELL, P. (2005). ATM activation and its recruitment to damaged DNA require binding to the $C$ terminus of Nbs1. Mol Cell Biol 25: 5363-5379.

ZEMAN, M.K. and CIMPRICH, K.A. (2013). Causes and consequences of replication stress. Nat Cell Biol 16: 2-9.

ZOU, L. and ELLEDGE, S.J. (2003). Sensing DNA damage through ATRIP recognition of RPA-ssDNA complexes. Science 300: 1542-1548. 


\section{Further Related Reading, published previously in the Int. J. Dev. Biol.}

Control of timing of embryonic M-phase entry and exit is differentially sensitive to CDK1 and PP2A balance Mohammed El Dika, Damian Dudka, Claude Prigent, Jean-Pierre Tassan, Malgorzata Kloc and Jacek Z. Kubiak Int. J. Dev. Biol. (2014) 58: 767-774 http://dx.doi.org/10.1387/ijdb.140101jk

Identification of the sperm motility-initiating substance in the newt, Cynops pyrrhogaster, and its possible relationship with the acrosome reaction during internal fertilization

Toshihiko Watanabe, Hideo Kubo, Shinya Takeshima, Mami Nakagawa, Manami Ohta, Saori Kamimura, Eriko Takayama-Watanabe, Akihiko Watanabe, and Kazuo Onitake

Int. J. Dev. Biol. (2010) 54: 591-597

http://dx.doi.org/10.1387/ijdb.092894tw

Nuclear reprogramming in zygotes

Chanchao Lorthongpanich, Davor Solter and Chin Yan Lim

Int. J. Dev. Biol. (2010) 54: 1631-1640

http://dx.doi.org/10.1387/ijdb.103201cl

Cyclin B2/cyclin-dependent kinase1 dissociation precedes CDK1 Thr-161 dephosphorylation upon M-phase promoting factor inactivation in Xenopus laevis cell-free extract

Franck Chesnel, Franck Bazile, Aude Pascal and Jacek Z. Kubiak

Int. J. Dev. Biol. (2007) 51: 297-305

http://dx.doi.org/10.1387/ijdb.072292fc

Remodeling of sperm chromatin induced in egg extracts of amphibians.

$\mathrm{C}$ Katagiri and $\mathrm{K}$ Ohsumi

Int. J. Dev. Biol. (1994) 38: 209-216

http://www.intjdevbiol.com/web/paper/7981030
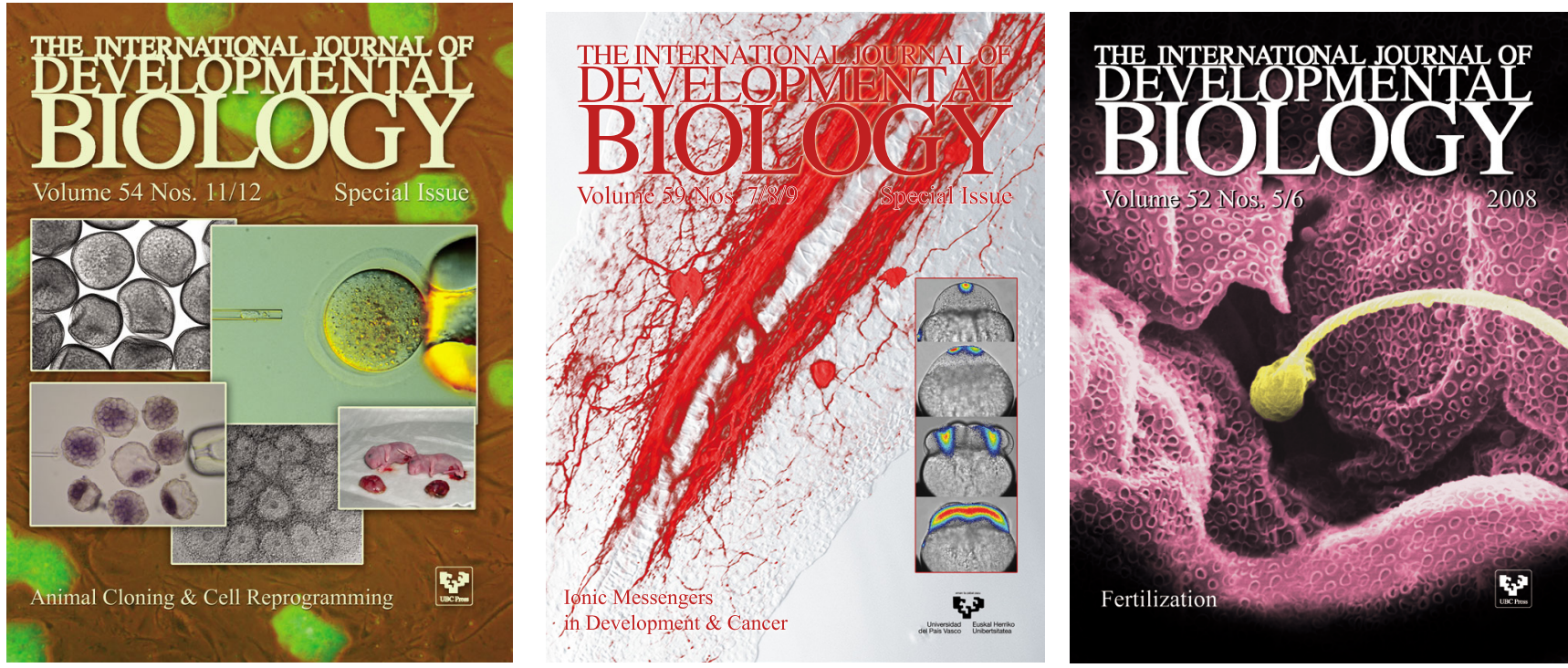